\title{
The Fall of the League of Nations
}

\author{
Felipe Rafael Robertos Matsushima \\ Southwest University of Science and Technology, Mianyang 621010, Sichuan, China
}

\begin{abstract}
After the end of World War I, the nations of the world decided to create an international body with the sole purpose of preventing another major conflict from happening again. As a result, the League of Nations came into fruition and from the beginning; it displayed flaws from within its covenant and its lack of enforceability. This paper will analyze why the League of Nations ultimately failed to achieve its goal of maintaining world peace in the context of Article 5 and unanimity as a voting mechanism. We can analyze the inadequacy of the organization from several angles. However, we will focus on the second Italo-Abyssinian war and the Spanish civil war, as it exposed the inability of the League of Nations to effectively deal with them.
\end{abstract}

Keywords: League of Nations, unanimity, Italo-Abyssinian war, Spanish civil war.

\section{The League of Nations}

The Paris Peace Conference held in January 1919; at the French Foreign Ministry, constituted the largest and most important diplomatic gathering since the Congress of Vienna of 1814-15. Seventy delegates representing the twenty-seven victorious nations, accompanied by hundreds of advisers, clerks and journalists, gathered at the French capital to participate in the peacemaking process that customarily follows the conclusion of great wars.

President Woodrow Wilson of the United States was actively involved during the peace talks in Paris and he outlined the three principal causes that led to the Great War as being:

"The practice of secret diplomacy, whereby political leaders surreptitiously concluded military alliances and diplomatic engagements to further their own nation's ambitions. The tendency of politically dominant nationality groups to oppress the ethnic minorities under their control. The political systems of autocracy, which enable a privileged elite to monopolize political power at the expense of the population at large".

The slogans that are the most often associated with Wilson's name, "the war to end all wars" and "the war to make the world safe for democracy", both symbolized the widespread anticipation that the most recent conflict was not entirely in vain. The disappointment of these optimistic expectations represented one of the most tragic episodes in modern world history. The member states who created the organization were optimistic for the future, and even though it achieved genuine accomplishments, instead the enormous gap between intention and achievement is what remains in the collective memory.

"Wilson, in his message on the conditions of peace delivered at a Joint Session of the Two Houses of the United States Congress on January 8, 1919, identifies the 14 points intended to serve as the program to achieve world peace".

Point 14 says the following:

"A general association of nations must be formed under specific covenants for the purpose of affording mutual guarantees of political independence and territorial integrity to great and small states alike."
After the end of the Great War and the signing of the Treaty of Versailles in June of 1919 came the creation of the League of Nations. The Covenant of the League of Nations outlines in its preamble the goals of this organization as to promote international co-operation and to achieve international peace and security.

Because of the domestic political circumstances that Wilson had not taken into account and an unforeseen illness, the United States was not to join the organization.

The United States' absence was one of the League's many weaknesses, and perhaps from the outset, made it impossible for the organization to satisfy the expectations it had aroused. The United States, together with absence of the Soviet Union (joined 1934, expelled 1939) and Germany (joined 1926, withdrew 1933), meant that the League of Nations became a predominantly European organization where its member states were not particularly keen on acting outside the continent unless their overall national interests were threatened.

From 1914 until 1919, the world experienced a war like nothing it had seen before, all corners of the world were involved in this conflict, and it caused tremendous social, economic, and political damage that caused a ripple effect that would affect everyone for generations to come.

\section{The decline of the League of Nations}

The League of Nations had failed to keep world peace primarily because the idea of collective security was far weaker than each individual State's desire to protect its national interests. President Woodrow Wilson of the United States saw the organization replacing the previous balance of power system with a centralized body comprised of powerful states acting together as trustees of world peace.

However, this notion of a centralized body meant that all members states would value the interests of the world first and their own national interests second. This enormous task did not fully take into consideration the different ideologies, economic dogmas, and political background behind each representative who had a seat at the League of Nation's Assembly. 
The start of World War 2 is attributed to several factors; however, this article is focused on the Italo-Abyssinian conflict and the Spanish civil war as main catalysts for the conflict.

These armed conflicts fell under the direct responsibility of the League of Nations, as members of the covenant aimed to achieve international peace and security, "by the acceptance of obligations not to resort to war, by the prescription of open, just and honorable relations between nations".

It is important to take into consideration that the examples put forward in the following paragraphs focus on the international political atmosphere that was taking place at the time. For an international organization such as the League of Nations, political factors are something that one cannot escape from, and they highly influence the development and decisions taken by it. The aforementioned conflicts reflect exactly how the international arena set the road taken by the member states of the League of Nations.

\section{Unanimity}

White expressed that "... the League was doomed to failure because the sovereign states continued to see national interests as paramount over collective interests despite the horror lived during World War I, a situation exacerbated by the requirement in Article 5 of the Covenant of unanimity for most substantive decisions of the Council or Assembly of the League".

Article 5 paragraph 1 of the Covenant established the following:

"Except where otherwise expressly provided in this Covenant or by the terms of the present Treaty, decisions at any meeting of the Assembly or of the Council shall require the agreement of all the Members of the League represented at the meeting."

At first glance, this article appears to be a complete acknowledgment of the general rule of unanimity as a necessary tool when international matters are concerned, with the exception of "matters of procedure." However, in reality, it restricts the decision-making process of the organization by allowing each member state the power to veto any resolution proposed by the Assembly of the Council when it did not fit its own domestic interests.

Williams explained what unanimity means for international matters and what it meant for the decision-making process of the League of Nations as:

“... Unanimity is the necessary rule for international matters in this sense that no independent state can be compelled without its consent to accept obligations; the existing society of states has legislature. States members of the League of Nations have, however, created in the League a persona of international law analogous to a body corporate in private law, but with strictly limited sphere of action or decision."

White elaborates further that by "overriding considerations of national power resulted in the dilution of the League's powers to such an extent that the question of imposition of sanctions under Article 16 became not one for the consideration of the Council or Assembly, but for each individual member... The failure to impose any sort of collective measure against aggressors meant the inevitable demise of the League."

Unanimity as a voting mechanism failed because it was impossible for states to keep their domestic interests below those of the international community. It also had the illusion that member states would always strive towards the common good and put aside their quarrels in order to pursue a genuine peaceful outcome that would avoid armed means in order to avoid the escalation of conflicts.

If a member state purposefully broke the covenants' agreements, it was in the League's best interests that all its members would act in accordance with what the assembly would require and never go against it. As we will see next, this would not be the case when Italy decided to engage in a military campaign against Ethiopia and when the Spanish civil war broke out. Both conflicts clearly reflected the inherit flaws in the League of Nations decision-making process and its inability to adequately enforce a peaceful resolution.

\section{The second Italo-Abyssinian War}

On October 3, 1935, Benito Mussolini and his fascist government invaded the east African state of Ethiopia, going publicly against all norms of international law and the international community. Italy proceeded to mobilize its troops, which shortly led to the beginning of the Second Italy-Abyssinian War. The animosity between these two states goes back even further to the Treaty of Wuchale and the subsequent First Italo-Ethiopian War, where the African nation defeated its European counterpart leading to the Treaty of Addis Ababa in 1896, which formally ended the conflict. By the end of the conflict, Italy had to recognize Ethiopia's independence from colonial rule. However, it would not take long for Italy to purse its expansionist agenda in Africa again. First, we must understand the treaties that bound Italy and Ethiopia before the Walwal incident, a series of skirmish battles between both sides that took place during the first week of December 1934 that ultimately propelled Mussolini's expansionist plans. Let us briefly look at three different treaties that limited the use of war as a method for dispute settlement; both Italy and Ethiopia were bound by these treaties. The first one was the Kellogg-Briand Pact.

Article I and Article II of the Kellogg-Briand Pact state, respectively:

The High Contracting Parties solemnly declare in the names of their respective peoples that they condemn recourse to war for the solution of international controversies, and renounce it, as an instrument of national policy in their relations with one another.

The High Contracting Parties agree that the settlement or solution of all disputes or conflicts of whatever nature or of whatever origin they may be, which may arouse among them, shall never be sought except by pacific means.

The Kellogg-Briand Pact, officially known as the General Treaty for Renunciation of War as an Instrument of National 
Policy, came into effect on August 27, 1928, and it served as an international agreement where signatory states promised not to resort to war as a means to solve disputes or conflicts. On paper, such words generated peace of mind when the articles were drafted, but it soon became apparent that it would help erase the legal distinction between war and peace; signatories began to engage in wars without officially declaring them.

The other two treaties that bound Italy and Ethiopia were the Treaty of Amity, Conciliation and Arbitration of August 2, 1928, under which the two governments took "to submit to a procedure of conciliation and arbitration," without having recourse to armed force, disputes not settled by "ordinary diplomatic methods."

The third one was the Covenant of the League of Nations, where it states on the Covenant's preamble that state parties "accept the obligations not to resort to war".

On January 3, 1935, the Ethiopian government reported to Geneva that Italian forces had actively participated in armed conflicts with Ethiopian forces over a well in the region of Walwal. As the Ethiopian government saw these events to be increasing, they requested the application of Article II, paragraph 2 of the Covenant of the League of Nations. The request came before the Council at its January session. The Italian government opposed to any intervention in the matter by the Council on the grounds that direct negotiations under the Treaty of 1928 had not been broken off. From the Council's session in January until September 4 of the same year, the question of Italo-Ethiopian relations did not come before the Council.

Emperor Haile Selassie I, the then regent Emperor of Ethiopia, decided to speak in front of the Assembly of the League of Nations in June of 1936. In his speech, he addressed issues like collective security where he mentioned "... it is the very existence of the League of Nations. It is the value of promises made to small States that their integrity and their independence shall be respected and ensured".

Emperor Salassie also raised a question to the members of the Assembly in order for the League to act and to change whatever was necessary to protect all of its member States.

"Your Assembly will doubtless have laid before it proposals for the reform of the Covenant and for rendering more effective the guarantee of collective security. Is it the Covenant that needs reform? What undertakings can have any value if the will to keep them is lacking?"

Finally, he pleaded for help, something that unfortunately only came in the form of weak sanctions by the League of Nations.

"I ask the fifty-two nations, who have given the Ethiopian people a promise to help them in their resistance to the aggressor, that are they willing to do for Ethiopia? And the great Powers who have promised the guarantee of collective security to small States on whom weighs the threat that they may one day suffer the fate of Ethiopia, I ask what measures do you intent to take?
Representatives of the World, I have come to Geneva to discharge in your midst the most painful of the duties a head of a State. What reply shall I have to take back to my people?".

During the eight months that it took for this issue to be brought up again by the Council, the Italian government was already mobilizing troops and equipment in order to prepare for further engagement in North Africa. However, the League of Nations still did nothing to stop this process from developing any further.

Zimmern also questioned, "Why was a State Member of the League allowed to make open and elaborate preparations for aggression upon another Member of the League not only without hindrance but without criticism or discussion of any kind at the Council?"

He gives a two-point answer to this question. First, the adoption of such action by the Council would have destroyed the last possibility of settling the dispute by conciliation. He goes on to argue that in certain circumstances, precautionary measures may produce the opposite effect from that for which they are designed. The Italian government would undoubtedly have regarded the adoption of such measures as derogatory to its prestige as a Great Power and might have withdrawn from the League of Nations.

Zimmern's second answer to this question was based on the adoption of preventive measures that would have required unanimity on the Council, including the vote of the Italian representative. As we recall from the Unanimity section on the League of Nations voting system, this particular process would give Italy and virtually any other state the power to veto decisions that were not in accordance with their particular domestic interests.

"On October 5th, forty-eight hours after the outbreak of hostilities, the Council appointed a Committee of Five to 'study the situation' and to 'enable it to make a decision'. This committee had two questions to answer: First, is there a state of war between Italy and Ethiopia? Second, if so, has there been recourse to war in violation of Articles 12, 13, or 15 of the Covenant?"

Article 12 Covenant of the League of Nations says the following:

The Members of the League agree that, if there should arise between them any dispute likely to lead to a rupture they will submit the matter either to arbitration or judicial settlement or to enquiry by the Council, and they agree in no case to resort to war until three months after the award by the arbitrators or the judicial decision, or the report by the Council. In any case under this Article the award of the arbitrators or the judicial decision shall be made within a reasonable time, and the report of the Council shall be made within six months after the submission of the dispute.

The committee concluded that the Italian government had recourse to war contrary to its engagements under Article 12 of the Covenant. This report was submitted to the Council on Monday, October 7; of the fifteen members present, all but the Italian representatives answered in the affirmative. 
An additional assembly took place from October 9 to the $12^{\text {th }}$. Fifty of the fifty-four States represented at the time accepted the Council's conclusions; Italy, Austria, Hungary, and Albania did not. Italy's refusal was obvious, and the response by the other three had the same answer, saying that their alliance with Italy was more important than the Covenant of the League of Nations. This notion of placing a higher priority on domestic security and interests is well reflected by Austria's, Hungary's, and Albania's position on the matter. They would rather turn their back on the views that the vast majority of the Assembly had on Italy's involvement in Africa than damage their current diplomatic and economic links with Mussolini's regime.

It seemed like more than the political implications were far more important to the members of the League, especially for those in the Council. After having all the proof necessary and all the facts indicating that Italy had in fact, violated the principles of the Covenant, the Council did not have the resources nor the unanimous will of the member States to protect Ethiopia.

Publicly stating that Italy was the aggressor and that they were in fact, the ones that bore the guilt in this armed conflict was not enough to stop Mussolini and his forces from continuing the expansionist campaign in North Africa.

After moral condemnation of the conflict was fixed on Italy, the conflict did not seem to be deescalating. It was then that the League decided to impose sanctions against the Italian government on November 2, 1935. There were five proposals that the League asked members to follow. These proposals recommended areas, which would regulate certain aspects that would encourage the Italian government to cease its campaign. An arms embargo was set on Italy, and all members States were asked to enforce it. Stopping loans and credit to the Italian government was also one of the strategies that were thought to prevent Italy from being able to fund its campaign in Ethiopia. More financial damage was sought by refusing Italian goods, and all Member States were asked not to allow them inside their borders. The League also asked all member States to support each other during the enforcement of these proposals, and if one State was being affected by the lack of trade with Italy, other members should help that State by allowing the trade of similar products to those of Italian manufacture.

The problem with these sanctions, according to Baer, was that they helped the Italian government and its movement to fascism. In Italy and among the Italian people, "the sanctions only intensified and popularized the Ethiopian war. The nationalist response was the 'safety valve' for the release of accumulated fears, angers and frustrations." These sanctions mainly focus on mechanisms of war and economic restrictions but do not cover what as the necessary means to win a modern mechanized war, such as coal and crude oil. Ristuccia also asserts that even if the League had extended the sanctions to cover those materials, the outcome of the Italian campaign would not have been any different.

\section{The Spanish Civil War}

As we mentioned before, the Spanish civil war was one of the main catalysts of World War II, and the League of Nations' policies towards this conflict forged the alliances that ultimately took place. It is important to reaffirm that even though the Spanish civil war started as a domestic armed conflict, the involvement of foreign States raised many questions as to the legality for the League to intervene or not.

\subsection{The Spanish Civil War and the Second World War}

The Spanish civil war had the particularity that it reflected two conflicts; it was both a domestic war and an international struggle between major European States. On the domestic side, we saw how the Nationalists led by General Francisco Franco sought to defeat the Loyalists of the Spanish Republic. The struggle became an international issue when Italy and Germany sought to help Franco's campaign. Meanwhile, France, Great Britain, and the USSR were supporting the Loyalists. France debated between intervention and non-intervention; Great Britain hoped for a diplomatic solution, and the USSR was the only one that truly tried to balance the conflict by aiding the Loyalists militarily. In the end, the Nationalists were able to secure victory, and by March 1939, the resistance had more than disappeared.

During the Spanish war, we could see how the alignments of what would become the Axis and the Allies were starting to settle down. European States were picking their side without knowing that a major armed conflict would arise in the end and that it would affect almost every corner of the world.

The First World War left Italy and Germany with a sentiment of frustration that Mussolini and Hitler looked to exploit by injecting a feeling of vengeance among their countrymen and, little by little, both nations hungered for dominance to be enforced on other States around them. To both dictators, “... war became not just a means to an end, but an end in itself and the final justification of their regimes. For them, there was no diplomacy needed, and Mussolini's declaration left that more than clear," "I was born never to leave Italians in peace... first Africa, now Spain, tomorrow something else."

These statements were more than a mere demonstration of power but defiance to the League of Nations and its members. After Mussolini was able to get away with the occupation of Ethiopia, he felt like further expansionist moves made by his regime would encounter the same weak response.

Adolf Hitler saw the Spanish civil war as an opportunity to aid Francisco Franco and his ideals. He used this conflict to "tie up the energies of both allies and his enemies, and to wear down his foreign opponents in a war of nerves."

In July 1936, both Hitler and Mussolini were sending military aid to Franco, hoping for the Nationalists to defeat the Loyalists as soon as possible. When the longed victory by Franco's forces failed to materialize itself, Hitler stopped providing said military aid as he did in the beginning and only supplied the necessary to keep the war efforts going and remain in Franco's steam; Mussolini, however, expanded his military commitment to Spain and to the Nationalists. 
When Germany and Italy left the Non-Intervention Committee, a body that only served as an agency created to veil over the intervention efforts made by some States in the Spanish war, the hopes of containing the war within the borders of Spain had vanished. The ever so diplomatic British government had "rightly designated Germany as the most dangerous potential foe, and the British Chiefs of Staffs were appalled to watch the course of events by 1935 create the possibility that Japan and Italy might become opponents as well". With the failure of sanctions over Ethiopia, the Foreign Office and the Committee of Imperial Defense set a high priority on restoring friendly relations with Italy.

The British government seemed to be taking an extremely pacifist attitude towards the conflict in Spain, and as the Chiefs of Staff reported in late 1938, "war against Japan, Germany, and Italy simultaneously is a commitment which neither the present nor the projected defense forces are designed to meet, even if we were in alliance with France and Russia". Their focus at the time was to pursue a policy that would ensure the neutrality of Spain regardless of the outcome of the civil war. At the same time, France had the same approach and faced even greater threats geographically, "having common borders with Germany, Italy and Spain, France would have great difficulty defending herself..." also, strategic routes linking France with North Africa, a necessary supply route in the case of war, would be threatened by a hostile power in control of the Balearic Islands.

Not only did Mussolini threaten Great Britain militarily, but it also pushed it to the brink of humiliation. On April 16, 1938, the Anglo-Italian Accords were concluded, which tried to accommodate both States interests in the Mediterranean, but it also dealt a low blow to Great Britain for the Accord also included "de jure recognition of the Italian conquest of Ethiopia".

During Anglo-Italian Accords, also known as the Eastern Accords, the British and Italian governments agreed to observe the order in the Mediterranean and to refrain from any actions against the sovereignty of the Kingdoms of Saudi Arabia, Yemen (currently controlled by the British government), and Somalia (controlled by the Italian government). Ethiopia was not named in the agreements, but it was clear the British government intended to ignore Italian control there.

In the end, the British government was unable to gain Mussolini's "friendship". it instead gave him the confidence to commit more defying acts during the Spanish civil war while strengthening its bond with Hitler. On the other hand, the "French government was so preoccupied with the danger to its strategic position in the Mediterranean that it retreated diplomatically from central Europe". This allowed Hitler to move to this area without having to worry about a French intervention.

We can accurately identify that the Spanish civil war managed to contribute to the outbreak of the Second World War on several points. First, we can see how the power of the democratic States weakened, with Great Britain and France being unable, and at some point, unwilling to restrain Italy and Germany from aiding General Franco's Nationalist forces. In addition, Hitler and Mussolini were strengthened by the confidence provided to do as they pleased throughout the Spanish civil war without any major reprisal. By the end of the Spanish war, those who would become part of the Axis and Allies were clearly defined.

\subsection{The League of Nations and the Spanish Civil War}

Article 10 of the Covenant refers to the respect for "territorial integrity and existing political independence" of its members. However, this protection is only given when the State is victim to an act of aggression by an external force, and it did not include domestic armed conflicts. With this concept in mind, we can understand that a civil war would not be inside the jurisdiction of the League of Nations, and the State would have to handle the situation on its own.

During the draft of the Covenant, the wording of the League's purpose was "to secure peace, security and orderly government." However, General Bliss, plenipotentiary to the United States of America in the Paris Peace Conference, feared that the words "in order to secure... and orderly government", would imply that the League would be able to intervene in domestic incidents that may appear in the future. It was then that the term "orderly government" was erased from the Covenant, and instead, Article 10 included the phrase "... as against external aggression the territorial integrity and existing political independence."

In his 1938 article, Wilcox affirms that even though the Spanish civil war was an internal conflict, it had "complications of an international character" and as such, it "threatened world peace" and thus it "was of deep concern to the League". He also reiterates that to determine when a domestic conflict becomes such that it inflicts damage outside its borders and thus starts being an international issue is rather hard to define.

On November 27, 1936, the Spanish Loyalists fighting Franco's Nationalists formally invoked Article 11 of the Covenant. Their argument was that Germany, Italy had formally recognized Franco's government on November 18, and that these rebels (the Nationalists) were receiving aid from these two States. Furthermore, naval attacks from ships of unknown nationality had occurred inside Spain's national waters. For the Loyalists, such acts should have been considered as "affecting international relations which threatens to disturb international peace or the good understanding between nations upon which peace depends". As Article 11, paragraph 1 of the Covenant of the League of Nations states, "Any war of threat of war, whether immediately affecting any of the Members of the League or not, is hereby declared a matter of concern to the whole League."

As a response to these claims, Great Britain asked the Non-Intervention Committee to examine the situation regarding foreign volunteers that were present in Spanish territory to aid both sides of the conflict. Together with France, Great Britain also "invited powers to collaborate in an offer of mediation and in the establishment of a control system about the Spanish frontiers." 
When the League saw that Great Britain and France were engaged in efforts to prevent the Spanish civil war from spreading even further, they put out a resolution on December 12 which basically stated the same principle as the Non-Intervention Committee; "to respect the territorial integrity and political independence" and that "every state is under obligation to refrain from intervening in the internal affairs of another state". The league also invited its members who were parties to the Non-Intervention Committee "to spare no pains to render the non-intervention undertakings as stringent as possible and to take appropriate measures to ensure forthwith that the fulfillment of the said undertakings is effectively supervised."

The Loyalists were outraged by these remarks because, to them, the Council had refused to rescue an invaded member, and in endorsing non-intervention, had even supported a movement that directly handicapped the Spanish government. Julio Alvarez del Vayo went as far as saying on the Seventeenth Assembly that "the policy of non-intervention represented an innovation in the traditional rules of international law, for it means withholding means of action from a lawful government". With this statement, he meant that relations should remain the same with the Spanish government, and thus, the purchase of arms and ammunitions should be a possibility.

Months before the Second World War started, Wilcox had hoped for the outbreak to be stopped and stated, "organized force in the international community is ultimately necessary, for no legal order can long endure unless a stand is taken against those who break the law". It is a shame to look back and think how such integrated force by the international community never took place.

As Willard mentioned, "the hope of universal collective security through the League of Nations, which had suffered... a mortal blow in the Ethiopian war crisis of 1935, was finally buried in the Spanish Civil War".

It is clear to us that these two events were one of the main causes for the outbreak of the Second World War, and the mishandling of both severely crippled the stability of the international arena at the time.

\section{Conclusion}

With factors like the unanimity in the League's decision-making process, its ineffectiveness to stop Italy from advancing towards Ethiopia, and the unwillingness to intervene in the Spanish civil war, the League failed to achieve its most important goal, to maintain global peace.

Since its creation after the Great War, a war that was supposed to end all wars, the League of Nations was unable to stop World War II from breaking out. The lack of power combined with the Member State's lack of will led to its overall ineffectiveness. Sanctions imposed were not obeyed, ignored, and sometimes not imposed at all.

In the words of Sir Alfred Zimmern, when talking about what the League of Nations really was and what it was not meant to be:
"... The League of Nations was never intended to be, nor is it, a revolutionary organization. On the contrary, it merely seeks to provide a more satisfactory means for carrying on some of the business which these states (the League of Nations member States) transact with one another. It is not even revolutionary in the more limited sense of revolutionizing the methods for carrying on inter-state business. It does not supersede the older methods. It merely supplements them".

An organization that started with Woodrow Wilson's vision of a world with peace and free of war became a futile attempt that achieved almost none of the goals it was created for. More frustrating for President Wilson would have been to become the visionary that wanted to create the mighty League of Nations, while its senate and congress refused to join. The United States staying off the League also contributed to its lack of power.

Finally, with the outbreak of World War II in 1939, the League of Nations lost most of its almost non-existing power, and for the years that the war lasted, there were no meetings. On April $18^{\text {th }}, 1946$, "the League of Nations transfers all of its assets to the United Nations... signed by Wlodzimierz Moderow, representative of the United Nations, and Sean Lester, the last Secretary-General of the League of Nations".

At that moment, the League was no more, and the newly created United Nations Organization took over where it had left off. As shown by the United Nations Charter, Article 1, paragraph 1:

"To maintain international peace and security, and to that end: to take effective collective measures for the prevention and removal of threats to the peace, and for the suppression of acts of aggression or other breaches of the peace, and to bring about by peaceful means, and in conformity with the principles of justice and international law, adjustment or settlement of international disputes or situations which might lead to a break of peace."

\section{References}

[1] Agreement Between the United Kingdom of Great Britain and Northern Ireland and Italy regarding the questions of mutual concern consisting of a protocol and annexes. (1939) Rome.

[2] Baer, G. W. (1973). Sanctions and Security: The League of Nations and the Italian-Ethiopian War. International Organization, 165-179.

[3] Goodrich, L. M. (1947). From the League of Nations to United Nations. International Organization, 3-21.

[4] Keylor, W. R. (1996). The Twentieth-Century World: An International History. Oxford University Press.

[5] Morris Roberts, J. (1999). Twentieth Century: The History of the World 1901 to 2000. Penguin Books.

[6] Overton, N. (2020). Resolving the Dispute Between Italy and Ethiopia. Old Dominion University.

[7] Quigley, C. (1966). Tragedy and Hope: A History of the World in our Time. New York: Macmillan Company.

[8] Ristuccia, C. A. (2000). The 1935 Sanctions against Italy: Would coal and oil have made a difference? European Review of Economic History, 85-110. 
[9] Scott, W. R. (1978). Black Nationalism and the Italo-Ethiopian Conflict 1934-1936. The Journal of Negro History, 118-134.

[10] Selassie, H. (2021, 08 11). Appeal to the League of Nations. Retrieved from Mount Holyoke College: https://www.mtholyoke.edu/acad/intrel/selassie.htm

[11] United Nations Office at Geneva (2021,09 15) The League of Nations. Retrieved from https://www.ungeneva.org/en/history/league-of-nations

[12] White, N. (1993). Keeping the Peace: The United Nations and the maintenance of international peace and security. Manchester University Press.

[13] Wilcox, F. O. (1938). The League of Nations and the Spanish Civil War. Annals of the America Academy of Political and Social Science, 65-72.

[14] Willard, F. J. (1987). The Spanish Civil War and the Coming of the Scond World Wars. The International History Review, 368-409.

[15] Williams, J. F. (1925). The League of Nations and Unanimity. The American Journal of International Law, 475-488.

[16] Wilson, W., \& Link, S. A. (1984). The Papers of Woodrow Wilson.

[17] Yale University (2020, 12 28), Kellog-Briand Pact 1928, Retrieved from https://avalon.law.yale.edu/20th_century/kbpact.asp

[18] Zimmern, A. (1935). The League's Handling of the Italo-Abyssinian Dispute. Royal Institute of International Affairs, 751-768. 